\title{
An exploratory method to determine the plant characteristics affecting the final yield: A study on Echium amoenum Fisch. \& C.A. Mey. under different fertilizers application and plant densities
}

Mohsen Jahan ( $\nabla$ jahan@ferdowsi.um.ac.ir)

Ferdowsi University of Mashhad Faculty of Agriculture https://orcid.org/0000-0003-2259-5124

Mohammad B. Amiri

University of Gonabad

Parviz Rezvani Moghaddam

Ferdowsi University of Mashhad Faculty of Agriculture

\section{Research}

Keywords: Organic fertilizer, flower yield, path analysis, plant density, multivariate analysis

Posted Date: April 28th, 2021

DOI: https://doi.org/10.21203/rs.3.rs-454623/v1

License: (c) (i) This work is licensed under a Creative Commons Attribution 4.0 International License. Read Full License 


\section{Abstract}

Background: Employing of advanced statistical methods to quantify agricultural information has helped to carry out targeted planning to alleviate the problems of farmers, researchers and policy section. One of these exploratory methods, is multivariate statistical analysis that examines and models the relationship between variables. Considering the importance of Echium amoenum and its use growing trend in traditional medicine and the pharmaceutical industry, also the lack of information on the correlations between its yield and morpho physiological traits, the objective of this study was to determine the causality path in which the Echium amoenum characteristics affects the yield of Echium amoenum as regards of application of organic and chemical fertilizers under different plant densities.

Results: The employed method revealed that organic fertilizers increased flower yield compared with the control. The flower yield as a result of application of compost, vermicompost and cattle manure were increased by 25,28 , and 27 percent compared with the control, respectively. The results of multiple regression showed that variables of plant height, shoot dry weight, flower number per plant were the main factors affected the flower yield. The relative contribution of shoot dry weight was 16 and 25 percent more than plant height and flower number per plant, respectively.

Conclusions: Causality analysis identified that shoot dry weight per plant had indirect effect on flower yield in different paths, as mainly was imposed through plant height considering the path coefficients. this study suggests that optimum production of Echium amoenum with application of ecological inputs along with effective agronomical managements of the causal paths of flower yield forming, including increase in shoot yield and plant height could be achieved through an ecological cropping system with reduced costs and no health concerning due to agrochemicals residual.

\section{Introduction}

Currently, the use of eco-friendly inputs as approaches to achieve sustainable agriculture has been considered (Wu et al., 2005; Altieri et al., 2017). Undoubtedly, the application of organic fertilizers and manures especially in nutrient-poor soils in addition to its positive effects on all soil properties and the increase of its organic matter, can also be beneficial in economic, environmental and social aspects and can be a suitable and desirable substitute for chemical fertilizers in long-term (Mao et al., 2008; Lee, 2010). Application of animal manure increases soil yield, improves water holding capacity and improves soil aggregation and increases water use efficiency and increases crop yield (Raja Sekar and Karmegam, 2010). Organic compost and vermicompost in most parts of the world have been successfully used on a large number of agricultural products (Shamsodin et al., 2007; Doan et al., 2013). It was reported that the highest root growth rate and root relative growth rate of sorghum (Sorghum bicolor L.) were resulted from the combined application of vermicompost and mycorrhiza treatment (Kamaei et al., 2019). Introducing these organic fertilizers to soil improves nutritional, physical, chemical and biological aspects of soil ecosystem are also improved (Robin et al., 2001; Singh et al., 2011; Coleman and Callaham, 2017). In a study the effect of different organic fertilizers on the quantitative and qualitative properties of several medicinal plants was investigated, it was reported that vermicompost increased Echinaceae purpurea L. plant height and increased fresh and dry shoot weight of Melissa officinalis L. (Delate, 2000). It was reported the application of organic fertilizers, especially vermicompost, on Calendula officinalis L. resulted in a significant increase in the number of branches per plant and the flower number per plant (Rezaee and Baradaran, 2011). It was reported that application of 
vermicompost increased dry matter of tomato (Lycopersicum esculentum L.) also improved nitrogen uptake efficiency in organic tomato production (Ebrahimi et al., 2019).

Plant density, as an agronomical management practice, plays an important role in the yield of different crops, so identifying the optimum plant density is one of the basic principles of crop production (Ibrahim, 2012). A balanced increase in plant density will accelerate canopy closure, increase leaf area, increase productivity of environmental resources, reduce weeds and ultimately improve the yield and yield components of different plants (Ndabamenye et al., 2013; Chauhan and Abugho, 2013). It is remarkable that at high plant densities, leaf loss rate increased and consequently. It has negative effects on the quantitative and qualitative characteristics of the plant, due to shading and competition of plants for light and scarcity of available resources, as well as greater susceptibility of plants to pathogens, (Zhang et al., 2012). In a study, the effect of different plant densities (12.5, 16.6 and 25 plants $\mathrm{m}^{-2}$ ) on yield and yield components of Coriander (Coriandrum sativum L.) was studied and reported that, the number of umbrellas per plant, 1000-seed weight and plant dry weight decreased with increasing density (Akhani et al., 2012). In another experiment, the effect of different plant densities on yield and yield components of a medicinal plant (Hibiscus sabdariffa L.) was studied and reported that with increasing the distance between planting rows from 50 to $100 \mathrm{~cm}$, flower yield increased (Mir et al., 2011).

In recent years, the use of advanced statistical methods to quantify agricultural information has helped to carry out targeted planning to alleviate the problems of farmers, researchers and policy section. One of these methods, which is widely used in all sciences disciplines today, particularly agricultural sciences, is multivariate statistical analysis that examines and models the relationship between variables (Kerlinger and Pedhazur, 1973). One of the exploratory multivariate methods as an elaborating statistical method in analyzing and explaining many phenomena is causality analysis or path analysis method. Causality analysis is a precise analytical tool to determine the share of direct and indirect effects of one variable with the other ones, since many studies have found that one variable not only has a direct effect on the other variable, but also indirectly through other variables affects those (Toebe and Filho, 2013; Guler et al., 2001). In other words, causality analysis divides the correlation coefficient between the two variables into a direct and indirect effects (Cramer, 2003; Everitt and Dunn, 1991). In a study, the relationships between yield and yield components of spring safflower (Carthamus tinctorius L.) were investigated and reported that biological yield, number of pod and branch and number of grains per pod were effective on grain yield, also according to the results of stepwise regression, whereas path analysis results showed that only two of the four traits (biological yield and number of pods per plant) effectively affected grain yield (Omidi Tabrizi, 2003).

Echium amoenum Fisch. \& Mey. is a perennial herb, Boraginaceae family plant, and is a valuable herb due to excellent medicinal properties (Mehrabani et al., 2005). This plant has been distributed across the northern parts of the country as wild vegetation (Sayyah et al., 2009). In traditional medicine, the petals of this plant are used as diuretics, analgesics, diaphoretic, and treat for high blood pressure (Nooriyan Soroor et al., 2013; Hornok, 1992). Considering the importance of Echium amoenum and its use growing trend in traditional medicine and the pharmaceutical industry, also the lack of information on the correlations between its yield and morpho physiological traits, this study was conducted aimed to determine the causality path in which the borage characteristics affects the yield of Echium amoenum as regards of application of organic and chemical fertilizers under different plant densities.

\section{Materials And Methods}




\section{Site description}

Field studies were conducted during the 2013-14, 2014-15 and 2015-16 growing seasons at the Research Farm Station of Agriculture Faculty, Ferdowsi University of Mashhad, Iran (latitude: $36^{\circ} 15^{\prime} \mathrm{N}$; longitude: $59^{\circ} 28^{\prime} \mathrm{E}$; elevation: $985 \mathrm{~m}$ above sea level). The Research station was located in Kashaf-rood watershed in northeast of the country in a semi-arid region with mean annual precipitation of $252 \mathrm{~mm}$ and temperature of $15^{\circ} \mathrm{C}$. Documented declaration of cropping history of the land which experiment was conducted in confirmed that it had been under fallow for the past three years, with no agrochemicals chemicals consumed or imported in (Research Station Archive).

Soil samples were taken at $0-30 \mathrm{~cm}$ depths and analyzed for some physiochemical properties (FAO, 2008) before conducting the experiment (Table 1).

Table 1

Soil properties of the experimental field

\begin{tabular}{|llllll|}
\hline Soil texture & Nitrogen $(\mathrm{ppm})$ & Phosphorous (ppm) & Potassium (ppm) & pH & $\begin{array}{l}\text { EC } \\
\text { (dS.m- } 1)\end{array}$ \\
\hline Silty loam & 15.7 & 13.4 & 417 & 7.3 & 1.1 \\
\hline
\end{tabular}

\section{Experimental design}

A split plot arrangement based on a RCBD design with three replications was conducted. Three plant densities (10, 5 and 3 plant $\mathrm{m}^{-2}$ ) were assigned to the main plots and five different types of organic and chemical fertilizers (compost by $10 \mathrm{t} \mathrm{ha}^{-1}$, vermicompost by $7 \mathrm{t} \mathrm{ha}^{-1}$, cattle manure by $30 \mathrm{t} \mathrm{ha}^{-1}$, chemical nitrogen fertilizer as Urea by $180 \mathrm{~kg} \mathrm{ha}^{-1}$ and the control) were assigned to the sub plots. Since Echium amoenom is a perennial plant, the experimental blocks and plots containing the underground parts and crown of borage plants of the first growing season were reserved intact for the second and third cropping year.

\section{Soil \& treatments preparation and crop management}

Minimum tillage was carried out to prepare the soil with emphasis on ecological soil cultivation operations, so that after a shallow disk, plots of $2.5 \times 5 \mathrm{~m}$ with a distance of 1 meter between, to avoid nutrients mixing due to irrigation consisting of 6 rows were arranged to sow the borage seeds on the middle of rows.

To applying organic fertilizers, the amounts of NPK in compost, vermicompost and cattle manure were determined (the results of the analysis of organic fertilizers used in the experiment shown in Table 2), then according to NPK requirements of Echium amoenum (Najafpoor Navaee, 2002) as well as taking into account the local farmers recommendations, the needed amounts of fertilizers were determined. Pure nitrogen by $90 \mathrm{~kg} \mathrm{ha}^{-1}$ (this amount of pure nitrogen was provided by $180 \mathrm{~kg}$ urea fertilizer containing $46 \% \mathrm{~N}$ ), half of which at the time of sowing and the other half after thinning operation were applied, while in the second cropping year (2014-15), the same amount of fertilizer was added in two stages (beginning of regrowth and four-leaves stages in the second year).

In late February 2013, organic fertilizers were broadcasted on the soil surface uniformly and immediately were mixed into the soil (a depth of $30 \mathrm{~cm}$ ) of related plots using a spade. In late February 2014, to promote the plants 
regrowth, the same amount of fertilizers were added into the soil on the side of planting rows of the related plots in a depth of $15 \mathrm{~cm}$.

Table 2

Chemical analysis results of organic fertilizers used in the experiment.

\begin{tabular}{|llll|}
\hline Type of organic fertilizer & $\begin{array}{l}\text { Nitrogen } \\
\text { (\%) }\end{array}$ & $\begin{array}{l}\text { Phosphorous } \\
\text { (\%) }\end{array}$ & $\begin{array}{l}\text { Potassium } \\
\text { (\%) }\end{array}$ \\
\hline Compost & 0.64 & 0.44 & 0.49 \\
\hline Vermicompost & 0.89 & 1.53 & 0.96 \\
\hline Cattle manure & 0.21 & 0.29 & 1.04 \\
\hline
\end{tabular}

Seeds were sown on April 5, 2013. Replanting was done after seed emergence where needed. Plots were immediately irrigated after sowing and later at 7-days interval. After reaching the plant to a 4-leaves stage, thinning was carried out to reach the appropriate density. Borage plants were established in the first year and no sampling or measurement was done during this growing season (2012-13). The data of this study are recorded from the second and third year of experiment (2013-14, 2014-15).

To control weeds, weeding was done three times in the first year (15, 30 and 45 days after planting, respectively) and (30 days after plant regrowth in second and third years. No herbicides, pesticides and chemical fungicides were used to prepare the soil during the growing seasons in three years of the study.

\section{Plant sampling and measurements}

At the spring of the second and third years (2015-16) during of the flowering season (April 6, to June 20) the flowers of all experimental plots were harvested daily (borage is identified with an undetermined growth pattern) then fresh and dry weights of flowers were measured. Harvested flowers were air dried under the shadow avoiding direct sunlight. The total dry weight of flowers during the flowering period was considered as the dry flower yield per plot. Three plants per plot were randomly selected and the flower number were counted during the flowering period.

At the end of the growing season, with the onset of seed ripening and plant shoot drying, three plants were randomly selected from each plot and traits including shoot yield, branch number, branch length, plant height and their canopy diameters were measured. To determine seed yield, total plants of all experimental plots were harvested and seed weight was determined.

\section{Data statistical analysis}

A normality test was already performed. Transformation was also performed for numerical data where needed. To ensure uniformity of treatment variances, the Bartlett's test was performed. Since there was no statistical difference between experiment data of two years (2014-15, 2015-16), thus the mean of each trait values during two years were reported. Analysis of variance (ANOVA) and graph plotting were done using SAS Ver.9.1, Slide Write Ver.2 and Microsoft Excel Ver. 14. All mean comparisons were performed by Duncan's multiple range test (DMRT) at $5 \%$ probability level. Growth characteristics affecting dry flower yield were determined using multiple regression and Minitab Ver.16 software. In order to find out the causal relationships between yield and growth characteristics affecting it, causality analysis was performed (Everitt and Dunn, 1991). 


\section{Results}

\section{Shoot yield}

The effect of plant density on shoot yield was significant (Table 3), as the highest shoot yield per plant resulted from medium density ( 5 plant $\mathrm{m}^{-2}$ ). This plant density increased yield by 34 and $47 \%$, compared with densities of 10 and 3 plant $m^{-2}$, respectively. Different organic and chemical fertilizers had a significant effect on shoot yield (Table 3). All the organic fertilizers had a positive effect on shoot yield as shoot yield as a result of application of compost, vermicompost and cattle manure increased by 25,7 and $19 \%$, respectively, compared with the control. The chemical fertilizer also resulted in $17 \%$ increase in shoot yield compared with the control. Compost and cattle manure increased shoot yield by $10 \%$ and $2 \%$, respectively compared with chemical fertilizer.

Table 3

Analysis of variance (mean of squares) of some growth characteristics and yield of Echium amoenum affected by different types of fertilizers and plant densities.

\begin{tabular}{|c|c|c|c|c|c|}
\hline & \multicolumn{3}{|c|}{ Mean of squares } & \multirow[b]{2}{*}{$\begin{array}{l}\text { Flower number per } \\
\text { plant }\end{array}$} & \multirow[b]{2}{*}{$\begin{array}{l}\text { Dry flower } \\
\text { yield }\end{array}$} \\
\hline & d.f & $\begin{array}{l}\text { Shoot yield per } \\
\text { plant }\end{array}$ & $\begin{array}{l}\text { Plant } \\
\text { height }\end{array}$ & & \\
\hline Block & 2 & $8.80 \mathrm{~ns}$ & $109.95 \mathrm{~ns}$ & $221078 n s$ & $339294 n s$ \\
\hline Plant density & 2 & $48116.71^{\star *}$ & $0.82 \mathrm{~ns}$ & $2810317 \star \star$ & $13075569 * *$ \\
\hline Fertilizer & 4 & $3396.94^{\star \star}$ & $540.38^{* *}$ & $1722380 \star *$ & $2183909 * \star$ \\
\hline $\begin{array}{l}\text { Plant } \\
\text { density×Fertilizer }\end{array}$ & 8 & $9373.31^{\star \star}$ & 122.40ns & $923445^{\star \star}$ & $2497218^{\star \star}$ \\
\hline Experimental error & 28 & 305.51 & 74.91 & 191739 & 266634 \\
\hline CV (\%) & - & 10.36 & 9.48 & 17.58 & 16.84 \\
\hline
\end{tabular}

Interaction effects of plant density and organic and chemical fertilizers on shoot yield showed that the highest (312.15 g per plant) and the lowest shoot yield (61.28 g per plant) were obtained from treatments of 5 plants $\mathrm{m}^{-2}$ plus compost fertilizer and 3.3 plant $\mathrm{m}^{-2}$ plus control, respectively (Table 4). 
Table 4

Mean comparisons of interaction of different densities and organic and chemical fertilizers application on some characteristics and yield of Echium amoenum

\begin{tabular}{|c|c|c|c|c|c|}
\hline & $\begin{array}{l}\text { Type of } \\
\text { fertilizer }\end{array}$ & 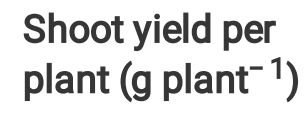 & $\begin{array}{l}\text { Plant } \\
\text { height } \\
\text { (cm) }\end{array}$ & $\begin{array}{l}\text { Flower number } \\
\text { per plant }\end{array}$ & $\begin{array}{l}\text { Dry flower yield } \\
\left(\mathrm{kg} \mathrm{ha}^{-1}\right)\end{array}$ \\
\hline \multirow{5}{*}{$\begin{array}{l}\text { Density of } 3 \\
\text { plants per } \mathrm{m}^{-2}\end{array}$} & Compost & 151.00ef & $99.00 \mathrm{ab}$ & 2268.1ed & $3914.4 a b$ \\
\hline & Vermicompost & $96.12 \mathrm{~h}$ & $86.33 a-c$ & $2594.9 b-d$ & $4340.7 a$ \\
\hline & Cattle manure & $126.33 f-h$ & $90.00 a-c$ & $3348.3 b$ & 2996.6bc \\
\hline & $\begin{array}{l}\text { Chemical } \\
\text { fertilizer }\end{array}$ & 170.98de & $101.66 a$ & $2489.8 \mathrm{~cd}$ & $4392.1 \mathrm{a}$ \\
\hline & Control & 210.01c & $78.00 \mathrm{c}$ & $2528.9 b-d$ & 4219.3a \\
\hline \multirow{5}{*}{$\begin{array}{l}\text { Density of } 5 \\
\text { plants per } \mathrm{m}^{-2}\end{array}$} & Compost & $312.15 a$ & 101.33a & 2178.3 & $3654.0 \mathrm{ab}$ \\
\hline & Vermicompost & $262.27 \mathrm{~b}$ & $96.00 a b$ & $2535.7 b-d$ & $4242.9 a$ \\
\hline & Cattle manure & $217.65 c$ & $98.66 a b$ & $4177.7 a$ & $3580.2 a b$ \\
\hline & $\begin{array}{l}\text { Chemical } \\
\text { fertilizer }\end{array}$ & $207.19 c$ & $82.33 b c$ & $2576.3 \mathrm{~b}-\mathrm{d}$ & $2354.4 c$ \\
\hline & Control & 161.14de & $77.66 \mathrm{c}$ & $2650.4 b-d$ & $2142.7 c$ \\
\hline \multirow{5}{*}{$\begin{array}{l}\text { Density of } 10 \\
\text { plants per } \mathrm{m}^{-2}\end{array}$} & Compost & 116.84gh & $100.00 \mathrm{a}$ & 1844.6de & $2504.4 c$ \\
\hline & Vermicompost & $105.58 \mathrm{~h}$ & $90.00 a-c$ & $3123.7 \mathrm{bc}$ & $2117.3 c$ \\
\hline & Cattle manure & $188.40 \mathrm{~cd}$ & $98.66 a b$ & 1871.6de & $3818.6 a b$ \\
\hline & $\begin{array}{l}\text { Chemical } \\
\text { fertilizer }\end{array}$ & $143.30 \mathrm{e}-\mathrm{g}$ & $86.00 a-c$ & $1640.9 \mathrm{e}$ & $913.8 d$ \\
\hline & Control & $61.28 i$ & $82.66 \mathrm{bc}$ & $1524.6 \mathrm{e}$ & $1183.4 d$ \\
\hline
\end{tabular}

In each column, means followed by the same letters are not significantly different $(p \leq 0.05)$, at $5 \%$ probability level based on Duncan's multiple range test.

With decreasing of density, the trend of shoot yield changes in different organic fertilizers was similar, so that under all organic fertilizers application condition, by decreasing densities down to 5 and 3 plants $\mathrm{m}^{-2}$, shoots yield was increased first and then decreased (Table 4). As it shown in Table 4, chemical fertilizer in 5 and 3 plant $\mathrm{m}^{-2}$ increased shoot yield by 22 and $62 \%$, respectively compared with the control.

\section{Plant height}

Although the effect of different densities on plant height was not significant, plant height was affected by different organic and chemical fertilizers (Table 3), so that all organic fertilizers increased plant height compared with the control. Application of compost, vermicompost and cattle manure resulted in increased plant height by 21,12 and $17 \%$, respectively, while the average plant height under these fertilizer applications was more than the control by $12 \%$. All of the organic fertilizers had superiority to chemical fertilizer regarding plant height, so the plant height as 
a result of application of compost, vermicompost and cattle manure were higher than chemical fertilizer by 10,4 and $6 \%$, respectively.

As it shown in Table 4, under all plant densities, organic fertilizers increased plant height compared to the control, as in density of 10 plant $\mathrm{m}^{-2}$, the plant height was higher under application of compost, vermicompost and cattle manure by 21,10 and $13 \%$ respectively. In density of 5 plant $\mathrm{m}^{-2}$, these amounts were by 23,19 and $21 \%$ and in density of 3 plant $\mathrm{m}^{-2}$ plant high were higher than the control by 17,8 and $16 \%$ respectively.

\section{Flower number per plant}

Plant density had a significant effect on the flower number per plant (Table 3), as with increasing plant density up

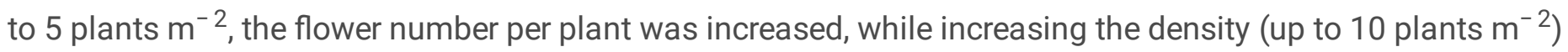
decreased the flower number per plant.

There was a significant difference between different organic and chemical fertilizers as regards the effect on flower number per plant (Table 3), as vermicompost and cattle manure increased this trait by 19 and $29 \%$, respectively, compared with the control. Application of these organic fertilizers also resulted in increased flower number per plant compared with the chemical fertilizer.

The interaction of the effect of organic fertilizers was different at different plant densities, as cattle manure in densities of 10 and 5 plants $\mathrm{m}^{-2}$, vermicompost in 3 plants $\mathrm{m}^{-2}$ were significantly higher than the other treatments. Compost, vermicompost, and cattle performing their best in increasing flower number per plant in densities of 10,3 and 5 plants per $\mathrm{m}^{-2}$ respectively (Table 4 ).

As it shown in Table 4, fertilizer in all densities had no significant effect on flower number per plant compared with control, but it seems that at 5 plant $\mathrm{m}^{-2}$ had effective impact on plant density as its application in 5 plants $\mathrm{m}^{-2}$ resulted in increased flower number per plant by 3 and $36 \%$, respectively, compared with application of fertilizer in 10 and 3 plant densities, respectively.

\section{Dry flower yield}

Dry flower yield was significantly affected by plant density (Table 3), as the highest flower yield (3972.6 kg ha-1) was obtained from density of 10 plants $\mathrm{m}^{-2}$ which was higher than densities of 5 and 3 plants $\mathrm{m}^{-2}$ by 21 and $47 \%$, respectively. The effect of organic and chemical fertilizers on dry flower yield was significant (Table 3 ), as all organic fertilizers increased dry flower yield compared with control. Dry flower yield resulted from application of compost, vermicompost and cattle manure were higher by 25,28 and $27 \%$ than the control, respectively. It is remarkable that all organic fertilizers (compost, vermicompost and cattle manure) had higher dry flower yield than chemical fertilizer by 24,27 and $26 \%$, respectively.

The interaction of plant density and fertilizers on dry flower yield was significant (Table 3), as by decreasing plant density, the efficiency of organic fertilizers in increasing dry flower yield was increased. Organic fertilizers had no significant effect on dry flower yield in density of 10 plants $\mathrm{m}^{-2}$, whereas compost, vermicompost and cattle manure increased dry flower yields by 41,49 and $40 \%$, respectively compared with the control. In density of 3 plants $\mathrm{m}^{-2}$ application of compost, vermicompost and cattle manure to soil increased dry flower yield by 53,44 and $69 \%$, respectively compared with the control (Table 4). 
As it shown in Table 4, the effect of organic fertilizers was different at different among plant densities, as in densities of 10 and 5 plants $\mathrm{m}^{-2}$ application of vermicompost, and in density of 3 plants $\mathrm{m}^{-2}$ cattle manure application resulted in more dry flower yield than other treatments.

\section{Relative comparison of growth characteristics of borage under plant densities}

Relative values of growth characteristics of borage under different densities shown in Fig. 1.

The advantage of the density 5 plant per $\mathrm{m}^{-2}$ considering fresh flower yield, shoot dry yield, dry flower yield is clearly revealed.

\section{Coefficients of correlation between traits}

As shown in Table 5, the number of branches per plant was the only trait that had a significant positive correlation with the flower number per plant. Correlations between fresh and dry weight of flowers per plant with all studied traits were significant except of flower number per plant and canopy diameter. Seed yield was also correlated with most physio morphological traits. The shoot yield per plant was significantly correlated with fresh and dry flower weight per plant, seed yield and branch length (Table 5).

Although there was a significant correlation between the number of branches per plant and most of the studied traits, its correlation with fresh weight $\left(r=0.55^{\star *}\right)$ and flower dry weight per plant $\left(r=0.56^{\star \star}\right)$ was more than the correlations of this trait with the other ones. Plant height and branch length were correlated with most of the studied traits, but the canopy diameter was not significantly correlated with any of the studied traits (Table 5).

The correlation between most studied morphological traits and dry flower yield was positive and significant, as the highest correlation was related to shoot yield per plant $\left(r=0.42^{\star *}\right)$, flower fresh weight $(r=0.40 \star *)$, and flower dry weight per plant $\left(r=0.36^{\star}\right)$, and plant height $\left(r=0.35^{\star}\right)$ (Table 5). The correlations of number of branches per plant, branch length and flower number per plant were also significant with dry flower yield, so by increasing each of them, dry flower yield would be improved (Table 5). 
Table 5

Coefficients of correlation between growth characteristics and yield of Echium amoenum affected by different types of fertilizers and plant densities

\begin{tabular}{|c|c|c|c|c|c|c|c|c|c|c|c|}
\hline Code & Trait & 1 & 2 & 3 & 4 & 5 & 6 & 7 & 8 & 9 & 10 \\
\hline 1 & $\begin{array}{l}\text { Dry flower } \\
\text { yield }\end{array}$ & 1 & & & & & & & & & \\
\hline 2 & $\begin{array}{l}\text { Flower } \\
\text { number per } \\
\text { plant }\end{array}$ & $0.30 *$ & 1 & & & & & & & & \\
\hline 3 & $\begin{array}{l}\text { Fresh flower } \\
\text { weight per } \\
\text { plant }\end{array}$ & 0.40 ** & 0.10 & 1 & & & & & & & \\
\hline 4 & $\begin{array}{l}\text { Dry flower } \\
\text { weight per } \\
\text { plant }\end{array}$ & $0.36 *$ & -0.01 & $0.76^{\star \star}$ & 1 & & & & & & \\
\hline 5 & $\begin{array}{l}\text { Seed } \\
\text { yield }\end{array}$ & 0.26 & -0.12 & $0.67^{\star \star *}$ & $0.67 * *$ & 1 & & & & & \\
\hline 6 & $\begin{array}{l}\text { Shoot yield } \\
\text { per plant }\end{array}$ & 0.42 *ᄎ & 0.16 & $0.59 * *$ & $0.47 * \star$ & $0.34 *$ & 1 & & & & \\
\hline 7 & $\begin{array}{l}\text { Branch } \\
\text { number per } \\
\text { plant }\end{array}$ & $0.31 *$ & $0.30 *$ & $0.55^{\star \star}$ & 0.56 ** & $0.35^{\star}$ & 0.22 & 1 & & & \\
\hline 8 & Branch length & $0.28 *$ & 0.09 & $0.42^{\star \star}$ & $0.41^{\star \star}$ & $0.42^{\star \star}$ & $0.35^{\star}$ & 0.22 & 1 & & \\
\hline 9 & $\begin{array}{l}\text { Plant } \\
\text { height }\end{array}$ & $0.35^{\star}$ & 0.03 & $0.41^{\star \star}$ & $0.38^{\star \star}$ & $0.34 *$ & 0.22 & 0.22 & $0.53^{\star \star}$ & 1 & \\
\hline 10 & $\begin{array}{l}\text { Canopy } \\
\text { diameter }\end{array}$ & -0.05 & 0.09 & -0.10 & 0.06 & -0.10 & 0.14 & 0.12 & 0.23 & 0.05 & 1 \\
\hline
\end{tabular}

\section{Identified growth characteristics affecting dry flower yield using multiple regression}

The results presented in Table 5 showed that the flower yield of Echium amoenum was correlated with most of the measured variables. Accordingly, multiple regression was used to analyze the relationship between flower yield as a function variable $(Y)$ and traits affecting it (independent variables, $X$ ). For this purpose, first of all the variables which are studied including number of branches per plant (X1), branch length (X2), plant height (X3), canopy diameter (X4), seed yield (X5), shoot yield (X6), fresh flower weight per plant (X7), dry flower weight per plant (X8) and flower number per plant (X9) were included in regression model. At the first step of the regression, the relationship between flower yield $(Y)$ and all the studied variables $(X 1, \ldots, X n)$ was estimated. The coefficient of determination of this model was calculated of $R^{2}=0.62^{\star \star}$. Then, the backward stepwise regression method was performed to eliminate the variables having weak coefficient of determination in model. Regression results showed that variables of plant height (X3), shoot yield per plant (X6) and flower number per plant (X9) were the main factors affecting the flower yield of Echium amoenum (Eq. 1).

Equation (1): $Y=0.01104+(0.32 \times X 6)+(0.27 \times X 3)+(0.24 \times X 9) r=0.55^{\star}$ 
Where: $\mathrm{Y}=$ dry flower yield $\left(\mathrm{kg} \mathrm{ha}^{-1}\right), \mathrm{X} 6=$ shoot yield per plant $(\mathrm{g}), \mathrm{X} 3=$ plant height $(\mathrm{cm})$, and $\mathrm{X} 9=$ flower number per plant.

\section{The causal paths of independent variables affect dry flower yield forming}

After identifying the main growth characteristics affecting dry flower yield using multiple regression, the direct and indirect effects of each of these characteristics were estimated using causality (path) analysis method. The effect of these characteristics on each other and on dry flower yield has been shown in Fig. 2.

Equations no. 2 to 7 were used to calculate the coefficients of direct effects of growth characteristics on each other and on dry flower yield shown in Fig. 2 (Everitt and Dunn, 1991):

Equation (2): Direct effect of shoot weight per plant on the plant height: $P_{21}=r_{12}$

Equation (3): Direct effect of shoot weight per plant on the flower number per plant: $P_{31}=r_{13}-P_{32} r_{12}$

Equation (4): Direct effect of plant height on the flower number per plant: $P_{32}=r_{23}-P_{31} r_{12}$

Equation (5): Direct effect of shoot weight per plant on the dry flower yield: $P_{41}=r_{14}-P_{42} r_{12}-P_{43} r_{13}$

Equation (6): Direct effect of plant height on the dry flower yield: $P_{42}=r_{24}-P_{41} r_{12}-P_{43} r_{23}$

Equation (7): Direct effect of flower number per plant on the dry flower yield: $P_{43}=r_{34}-P_{41} r_{13}-P_{42} r_{23}$

Calculated values of the direct and indirect effects of each of growth characteristics and analyzed correlation coefficients between these traits and dry flower yield are presented in Table 6. 
Table 6

Analyzed coefficients of correlation of the morphological characteristics affecting dry flower yield of Echium amoenum to direct and indirect effect

\begin{tabular}{|c|c|}
\hline \multicolumn{2}{|l|}{ Direct effect } \\
\hline Shoot weight per plant $\left(P_{41}\right)$ & 0.32 \\
\hline Plant height $\left(\mathrm{P}_{42}\right)$ & 0.27 \\
\hline Flower number per plant $\left(\mathrm{P}_{43}\right)$ & 0.24 \\
\hline \multicolumn{2}{|l|}{ Indirect effect of shoot per plant via } \\
\hline Plant height $\left(\mathrm{P}_{21} \times \mathrm{P}_{42}\right)$ & 0.0594 \\
\hline Flower number per plant $\left(\mathrm{P}_{31} \times \mathrm{P}_{43}\right)$ & 0.0384 \\
\hline Plant height and Flower number per plant $\left(\mathrm{P}_{21} \times \mathrm{P}_{32} \times \mathrm{P}_{43}\right)$ & 0.0002 \\
\hline \multicolumn{2}{|l|}{ Indirect effect of Plant height via } \\
\hline Flower number per plant $\left(\mathrm{P}_{32} \times \mathrm{P}_{43}\right)$ & 0.0012 \\
\hline $\begin{array}{l}\text { Total direct and indirect effects of shoot yield per plant } \\
\mathrm{P}_{41}+\left[\left(\mathrm{P}_{21} \times \mathrm{P}_{42}\right)+\left(\mathrm{P}_{31} \times \mathrm{P}_{43}\right)+\left(\mathrm{P}_{21} \times \mathrm{P}_{32} \times \mathrm{P}_{43}\right)\right]\end{array}$ & 0.418 \\
\hline $\begin{array}{l}\text { Total direct and indirect effects of plant height } \\
\mathrm{P}_{42}+\left(\mathrm{P}_{32} \times \mathrm{P}_{43}\right)\end{array}$ & 0.271 \\
\hline Residual effects (error) & 0.07 \\
\hline
\end{tabular}

The shoot weight per plant affected dry flower yield $\left(P_{31} \cdot P_{43}=0.0384\right)$, but when its indirect effect through plant height and flower number per plant on dry flower yield simultaneously calculated, this effect was not significant $\left(P_{43} \times P_{32} \times P_{21}=0.0002\right)$.

Plant height indirectly affected dry flower yield through flower number per plant $\left(P_{32}+P_{43}=0.0012\right)$, as increased plant height led to increased flower number per plant and increased number of flowers per plant in turn resulted in dry flower yield $\left(P_{42}+P_{32}+P_{43}=0.271\right)$. This finding is confirmed by performed regressions between traits which correlations amongst those were already revealed (Table 5), for instance increasing each of the shoot weight per plant, plant height and flower number per plant resulted in increased dry flower yield (Fig. 3).

As it shown in Fig. 4, there was a linear function between shoot weight per plant and plant height (Fig. 4a). On the other hand, increased plant height led to improved dry flower yield (Fig. 4b), so it is reasonable to expect that dry flower weight increases with increasing shoot yield.

\section{Discussion}


It seems that by reducing the number of plants per square meter, the positive effect of organic fertilizers on the growth characteristics of the plant was revealed obviously, probably due to more availability and synchrony of the nutrients in organic fertilizers to the plant needs. It seems that with decreasing plant density, plant access to growth resources such as light, water and nutrients is increased and resulted to improved growth characteristics of the plant including its height. Some researchers studied the effects of organic and chemical fertilizers on yield and essential oil percentage of basil (Ocimum basilicum L.) and reported that vermicompost-treated plants had higher plant height, leaf yield, shoot yield, fresh and dry yield than other treatments (Liang et al., 2005; Tahami Zarandi et al., 2010). The results of a study on sesame (Sesamum indicum L.) showed that the application of chemical fertilizers improved leaf nitrogen content and significantly increased plant photosynthesis and consequently the biological yield of plant through increased availability of nutrients in particular of nitrogen (Kumar et al., 1996).

The positive effects of organic fertilizers on the qualitative and quantitative characteristics of different plants have been emphasized in many studies (Lakhdar et al., 2011; D'Hose et al., 2014; Ebrahimi et al., 2019). It was reported that organic fertilizers increased activity of microorganisms in soil (Arancon et al., 2004) and improved soil physiochemical and biological properties, increased nutrient storage capacity (Arancon et al., 2005) and slow release of nutrients. Nutrients improved the growth characteristics of the plant, including its height. Physiologically, when water and nutrients are sufficiently supplied to the plant, the accumulated water in the cells increases and is transmitted to the adjacent cells by turgidity and eventually increases the plant height. The effect of organic fertilizers on the qualitative and quantitative characteristics of medicinal plants of Plantago ovate Forsk., Alyssum homolocarpum L., Lepidium perfoilatum L. and Lalementia iberica L. were investigated and it was reported that cattle manure treatment produced the highest plant height compared with the other treatments, while the height of all plants was higher than the control due to application of vermicompost, coffee compost and mushroom compost (Koocheki et al., 2013). The positive effects of vermicompost application on plant nutrition and growth was also reported for sorghum (Kamaei et al., 2019).

It seems that the average plant density played the most role in increasing the flower number per plant. In low plant density, flower number per plant decreased compared with the average plant density probably due to excessive access to food and growth resources by the plant. In high plant density, this decrease was related to plant competition over water and nutrients and lack of efficient use of resources.

Organic fertilizers appear to be likely to increase the flower number per plant by supplying the plant with the micro nutrients (Motta and Maggiore, 2013). Organic fertilizers might enhance number of flowers through improving soil microbial activities (Padmavathiamma et al., 2008; Ebrahimi et al., 2019), increasing water holding capacity (Shamsodin et al., 2007) and supplying more essential nutrients (Motta and Maggiore, 2013), increased photosynthesis and plant dry matter (Atiyeh et al., 2002; Ebrahimi et al., 2019), which eventually led to increased flowering. The effects of different organic and biological fertilizers on the safflower were studied and it was reported that vermicompost solely or combined with Nitroxin ${ }^{\circledR}$ and Nitrajin ${ }^{\circledR}$ biofertilizers improved the quality and quantity of the plant (Rezvani Moghaddam et al., 2013). In a same study, it was reported that application of $10 \mathrm{t}$ ha $^{-1}$ vermicompost increased flower number, plant height, 1000-seed weight, biological yield and essential oil content of Foeniculum vulgare Mill. (Darzi et al., 2006).

In high plant densities, it seems that intra-specific competition was increased and growth resources, particularly radiation, would not been adequately provided to the plant (Ndabamenye et al., 2013), thus resulted in a decrease in dry flower yield. In a study, the effect of distance between planting rows $(60,70$ and $80 \mathrm{~cm})$ and within rows (25, 35 and $45 \mathrm{~cm}$ ) on yield and yield components of Satureja khuzistanica Jamzad, was investigated. The results 
showed that the highest flower yield and canopy diameter were observed in $45 \mathrm{~cm}$ within row distance and density of 7 plant $\mathrm{m}^{-2}$ had the highest dry matter yield (Hekmati et al., 2012).

The vermicompost probably played an important role in supplying the water needed for the plant (Shamsodin et al., 2007) because of its high moisture holding capacity, thereby producing more flower dry yield. Cattle manure at low levels of plant density significantly increased dry flower yield probably through increased nitrogen release in soil (Motta and Maggiore, 2013). Some studies have shown that the application of organic fertilizers reduce the salinity effects and increase the uptake of phosphorus and nitrogen thus improve the qualitative and quantitative characteristics of plants (Sabahi et al., 2010; Ebrahimi et al., 2019). In a study, the effects of different levels of vermicompost $\left(0,5,10,15\right.$ and $\left.20 \mathrm{tha}^{-1}\right)$ on the qualitative and quantitative characteristics of German chamomile (Matricaria chemmomilla) were investigated. The highest dry and fresh flower yield, and the maximum plant height were obtained from vermicompost application of $20 \mathrm{t} \mathrm{ha}^{-1}$ (Haj Seyyed Hadi et al., 2013).

Flower yield is a complex feature that is influenced by many physiological processes and its measurable performance would be revealed in phenological, morphological, and physiological traits (Hobbs and Mahon, 1982). Weak correlations between some traits appeared to be related to differences in the time of traits measured, as traits such as flower number per plant and flower weight per plant were measured during flowering, while the traits such as plant height, number of branches per plant and canopy diameter were evaluated at the end of the flowering period. Therefore, causality analysis was performed to accurately determine the contribution of each of the traits to improvement of dry flower yield.

Although the yield of most crops, particularly medicinal plants, has increased over the past decades, but the morphological and physiological processes underlying this increase of yield are not well identified (Tollenaar, 1991). Researches revealed the positively correlation between the physio morphological traits and yield of medicinal plants including Mentha pulegium, Peppermint (Mentha piperita) and Thymus vulgaris (Mirzaee Nadooshan et al., 2001; Kukreja et al., 1992). If the origins of increased yield of medicinal plants are identified, paths to improve their actual potential by better crop management practice and effective nutrition supply may be identified (Fraser and Eaton, 1983). In this study physio morphological traits affecting yield Echium amoenum were identified using multiple regression and causality analysis.

The coefficients of Eq. 1 show the relative impact of changes in each of the variables in the model on flower yield. For example, the change in flower yield was 0.32 units per unit of change in shoot yield per plant, while this change would be 0.27 per unit increase in plant height. In other words, the relative share of shoot yield per plant was about $16 \%$ higher than that of plant height, implying some important growth characteristics of borage such as producing numerous branches and flower formation at the end of them and finally the effect of these traits on flower yield. However, to better interpret these results, the unit of measurement for each variable should also be considered, which is why multiple regression was performed on standardized traits data. Thus, due to the effects of different treatments (different types of fertilizer and plant densities) in the above model, it is possible to quantitatively evaluate the response of borage based on the rate of increase or decrease of the variables affected by the treatments.

According to Table 6, direct effect of shoot yield per plant on dry flower yield was more than direct effect of plant height via flower number per plant. Plant height had more direct effect on dry flower yield than flower number per plant. 
Shoot weight per plant affected dry flower yield indirectly in three ways:

(A) Indirect effect of shoot weight per plant through plant height $\left(P_{31}+P_{42}\right)$

(B) Indirect effect of shoot weight per plant through flower number per plant $\left(\mathrm{P}_{31}+\mathrm{P}_{43}\right)$

(C) Indirect effect of shoot weight per plant by plant height and number by flowers per plant $\left(P_{21}+P_{32}+P_{43}\right)$

As it shown in Table 6, shoot weight per plant had the most indirect effect on dry flower yield (0.0594), which resulted in increased dry flower yield mediated through plant height. It was reported that the yield of flowering branches of Camphorosma monspeliaca L. was positively correlated and affected by shoot yield. Also, the number of tillers that had the most direct effect on the yield of flowering branches was also indirectly affected by plant height (Abbaszadeh et al., 2011).

The results (Table 6) showed that the direct effect of plant height on dry flower yield $\left(P_{42}=0.27\right)$ was more than the indirect effect through flower number per plant $\left(P_{43} \times P_{32}=0.0012\right)$. In a study, investigation of morphological characteristics affecting yield of medicinal plant revealed that improvement of plant height and branch number per plant increased flowering branches yield (Abbaszade et al., 2011). The results of causality analysis indicated that flower number per plant had only a positive direct effect on dry flower yield. From a physiological point of view, the flower number in plants such as borage is the last component of yield and cannot transmit yield fluctuations (in this case, flowers) to another component, thus the causality analysis performed is fully consistent with the physiological bases. Comparison of morphological traits affecting dry flower yield showed that shoot weight per plant affected dry flower yield more than the other traits, as the total direct and indirect effects of shoot yield per plant was more than the other traits. Considering the paths coefficient affecting dry flower yield (Fig. 2), it seems that management practices and treatments that would increase shoot yield per plant would lead to improved yield of Echium amoenum. Results of a study on sunflower (Helianthus annus L.) showed that there were positive correlations between biological yield, shoot yield and grain yield (Amirian et al., 2013). In another study, shoot yield, plant height and number of grains per plant were identified as the most influential traits on the yield of Trigonella foenum-graecum L. (Singh et al., 2012). Some researchers reported that shoot yield, particularly umbrellas dry weight and 1000-seed weight of Coriandrum sativum L. were the most important traits affecting the yield of this medicinal plant (Dyulgerov and Dyulgerova, 2013). Guler et al., (2001) determined negative and significant relationship between 100-seed weight and seed yield of chickpea using path coefficient analysis.

\section{Conclusions}

The results showed that cultivation of borage with density of 5 plants $\mathrm{m}^{-2}$ and application of compost resulted to the highest flower yield. There was a significant positive correlation between dry flower yield and all studied growth characteristics except seed yield and canopy diameter. According to the results of multiple regression, shoot yield per plant, plant height and flower number per plant were identified as the main factors affecting dry flower yield, although the relative proportion of plant height compared with shoot weight per plant and flower number was higher by 16 and 25 percent, respectively. Causality analysis revealed that shoot weight per plant had the most direct effect on dry flower yield, while this trait through three paths (1- plant height, 2- flower number per plant, 3Plant height, and then flower number per plant) had an indirect effect on dry flower yield. The causality analysis also identified that shoot weight per plant seems affected dry flower yield through plant height, along with increasing shoot weight per plant, plant height was increased which in turn improved dry flower yield.

Page $15 / 21$ 
Conclusively, this study suggests that optimum production of Echium amoenum with application of ecological inputs along with effective agronomical managements of the causal paths of flower yield forming, including increase in shoot yield and plant height could be achieved through an ecological cropping system. Moreover, achieving more yield from organic fertilizers application than chemical fertilizer in this study, promises agrochemicals free and healthy production of this medicinal plant could be achieved from low input cropping systems or marginal farms using ecological inputs.

\section{Declarations}

\section{Supplemental Material}

There are no supplemental materials related to the manuscript.

\section{Ethics approval and consent to participate}

This research meets all the ethical guidelines, including adherence to the legal requirements of my country.

\section{Consent for publication}

The authors confirm no conflict of interest and agree with the submission of the manuscript to Plant Methods journal.

\section{Data Availability}

All used and created data are available on demand.

\section{Competing interests}

The authors declare that they have no competing interests.

\section{Funding Statement}

There is no funding received for conducting the research.

\section{Authors' Contributions}

The authors of this research paper have directly participated in the planning, execution, or analysis of this study. The authors read and approved the final edition of the manuscript. CRediT author statement: Mohammad Behzad Amiri: project administration, methodology, investigation, software. Mohsen Jahan: investigation, data curation, formal analysis, writing-original draft preparation writing-reviewing and editing. Parviz Rezvani Moghaddam: conceptualization, validation.

\section{Acknowledgement}

Partially Financial support of Vice President for Research and Technology, and Center of Excellence for Special Crops (CESC) of Ferdowsi University of Mashhad (FUM) is acknowledged.

\section{References}


1. Abbaszadeh B, Rezaee MB, Paknejad F. 2011. [Evaluation relationship between essential oil yield and some agriculture characters by using of path analysis of two ecotypes of Mentha longifolia (L.) Huds. Var. amphilema L.] Iran J Med Aroma Plants. 27:36-46. (In Persian with English Summary).

2. Akhani A, Darzi MT, Haj Seyed Hadi MR. 2012. Effects of biofertilizer and plant density on yield components and seed yield of coriander (Coriandrum sativum). Int J Agr Crop Sci. 4:1205-1211.

3. Altieri M, Nicholls C, Montalba R. 2017. Technological Approaches to Sustainable Agriculture at a Crossroads: An Agroecological Perspective. Sustainability. 9(3):1-13.

4. Amirian S, Golparvar AR, Nassiri B M. 2013. Character association, regression and path analysis in sunflower (Helianthus annus) hybrids. Technical Journal of Engineering and Applied Sciences, 3, 3640-3643.

5. Arancon NQ, Edwards CA, Bierman P, Welch C, Metzger JD. 2004. Influence of vermicompost on field strawberries. Bioresource Technol. 93:145-153.

6. Arancon NQ, Galvis PA, Edwards A. 2005. Suppression of insect pest populations and damage to plants by vermicomposts. Bioresource Technol. 96:1137-1142.

7. Atiyeh RM, Lee SS, Edwards CA, Arancon NQ, Metzger J. 2002. The influence of humic acid derived from earthworm-processed organic waste on plant growth. Bioresource Technol. 84:7-14.

8. Chauhan BS, Abugho SB. 2013. Effects of water regime, nitrogen fertilization, and rice plant density on growth and reproduction of lowland weed Echinochloa crus-galli. Crop Prot. 54:142-147.

9. Coleman DC, Callaham MA. 2017. Fundamentals of Soil Ecology. [accessed 2019 October 5]:[16 p.]. https://www.researchgate.net/publication/321148966_Fundamentals_of_Soil_Ecology_Third_Edition

10. Cramer D. 2003. Advanced Quantitative Data Analysis (Understanding Social Research). Open University Press; 2003. ISBN-10: 0335200591. 208 p.

11. Darzi MT, Ghalavand A, Rejali F, Sefidkon F. 2006. [Effects of biofertilizers application on yield and yield components in fennel (Foeniculum vugare)]. Iran J Med Aroma Plants. 22:278-292. (In Persian with English Summary).

12. Delate K. 2000. Heenah mahyah student from herb trail. Leopold center for sustainable agriculture. Annual Reports, Jowa State University. Ames (IA).

13. D'Hose T, Cougnon M, De Vliegher A, Vandecasteele B, Viaene N, Cornelis W, Van Bockstaele E, Reheul D. 2014. The positive relationship between soil quality and crop production: A case study on the effect of farm compost application. Appl Soil Ecol. 75:189-198.

14. Doan TT, Ngo PT, Rumpel C, Nguyen BV, Jouquet P. 2013. Interactions between compost, vermicompost and earthworms influence plant growth and yield: A one-year greenhouse experiment. Sci Hortic. 160:148-154.

15. Dyulgerov N, Dyulgerova B. 2013. Correlation and path coefficient analysis of productivity elements in coriander (Coriandrum sativum). J Cent Eur Agr. 14:1512-1517.

16. Ebrahimi E, Ghorbani R, Neimsdorff PVF. 2019. Effects of vermicompost placement on nutrient use efficiency and yield of tomato (Lycopersicum esculentum). Biol Agr Hort, DOI: 10.1080/01448765.2019.1671220

17. Everitt BS, Dunn G. 1991. Applied multivariate data analysis. Second edition, WIELY Publication.

18. Fraser J, Eaton GW. 1983. Applications of yield component analysis to crop research. Field Crop Abs. 36:787797.

19. 2008. Guide to laboratory establishment for plant nutrient analysis. Motsara MR, Roy RN. (Eds). [accessed 2017 Aug 8]:[219 p.]. http://www.fao.org/3/i0131e/i0131e00.htm

Page $17 / 21$ 
20. Guler M, Sait Adak M, Ulukan H. 2001. Determining relationships among yield and some yield components using path coefficient analysis in chickpea (Cicer arietinum). Eur J Agron. 14:161-166.

21. Haj Seyyed Hadi MR, Darzi MT, Riazi GH, Ghandarhari Z. 2013. [Evaluation of effect of vermicompost and aminoacids on yield and yield components of Matricaria chemmomilla]. Iran J Plant Ecosyst. 33:67-80..

22. Hekmati M, Hadian J, Tabaei Aghdaei SR. 2012. Evaluating the effect of planting density on yield and morphology of savory (Satureja khuzistanica Jamzad). Ann Biol Res. 3:4017-4022.

23. Hobbs SLA, Mahon JD. 1982. Variation, heritability, and relationship to yield of physiological characters in peas. Crop Sci. 22:773-779.

24. Hornok L. 1992. Cultivation and processing of medicinal plants. John Wiley, Chichester (UK). 338 p. ISBN 0471-923883-4

25. Ibrahim HM. 2012. Response of some sunflower hybrids to different levels of plant density. APCBEE Procedia. 4:175-182.

26. Kamaei R, Faramarzi F, Parsa M, Jahan M. 2019. The effects of biological, chemical, and organic fertilizers application on root growth features and grain yield of Sorghum, Journal of Plant Nutrition, 42:18, 2221-2233, DOI: 10.1080/01904167.2019.1648667

27. Kerlinger FN, Pedhazur EJ. 1973. Multiple regression in behavioral research. Holt, Rinehart and Winston, Inc, (NY).

28. Koocheki A, Amirmoradi Sh, Shabahang J, Kalantari Khandani S. 2013. [Effect of organic fertilizers on quantitative and qualitative characteristics of Plantago ovata Alyssum homolocarpum L., Lepidium perfoilatum L., and Lalementia iberica L.] Iran J Agroecol. 5:16-26. (In Persian with English Summary).

29. Kukreja AK, Dhawan OP, Ahuja PS, Sharma S, Mathur AK. 1992. Genetic improvement of mints: On the quantitative traits of essential oil of in vitro derived clones of Japanese mint (Mentha arvensis var piperaascens Holmes). J Essent Oil Res. 4:623-629.

30. Kumar AS, Prasad TN, Prasad UK. 1996. Effect of irrigation and nitrogen on growth, yield/oil content, nitrogen uptake and water-use of summer sesame (Sesamum indicum). Ind J Agron. 41:111-115.

31. Lakhdar A, Falleh H, Ouni Y, Oueslati S, Debez A, Ksouri R, Abdelly Ch. 2011. Municipal solid waste compost application improves productivity, polyphenol content, and antioxidant activity of Mesembryanthemum edule. J Hazard Mater. 191:373-379.

32. Lee J. 2010. Effect of application methods of organic fertilizer on growth, soil chemical properties and microbial densities in organic bulb onion production. Sci Hort. 124:299-305.

33. Liang Y, Si J, Nikolic M, Peng Y, Chen W, Jiang Y. 2005. Organic manure stimulates biological activity and barley growth in soil subject to secondary salinization. Soil Biol Biochem. 37:1185-1195.

34. Mao J, Olk DC, Fang X, He Z, Schmidt-Rohr K. 2008. Influence of animal manure application on the chemical structures of soil organic matter as investigated by advanced solid-state NMR and FT-IR spectroscopy. Geoderma. 146:353-362.

35. Mehrabani M, Ghassemi N, Sajjadi SE, Ghannadi A, Shams-Ardakani M. 2005. Main phenolic compounds of petals of Echium amoenum And C.A. Mey., a famous medicinal plant of Iran. Daru. 13:65-69.

36. Mir B, Ghanbari A, Ravan S, Asgharipour M. 2011. Effects of plant density and sowing date on yield and yield components of Hibiscus sabdarij in Zabol region. Adv Environ Biol. 5:1156-1161.

37. Mirzaee Nadooshan H, Rezaee MB, Jaimand K. 2001. Path analysis of essential oil-related characters in Mentha Flavour Frag J. 16:340-343. 
38. Motta SR, Maggiore T. 2013. Evaluation of nitrogen management in maize cultivation grown on soil amended with sewage sludge and urea. Eur J Agron. 45:59-67.

39. Najafpoor Navaee M. 2002. [Evaluation of effect of phosphorous and nitrogen fertilizers on seed yield of Echium amoenum.] Iran J Med Aroma Plants. 13:41-50. (In Persian with English Summary).

40. Ndabamenye T, Van Asten PJA, Blomme G, Vanlauwe B, Swennen R, Annandale JG, Barnard RO. 2013. Ecological characteristics and cultivar influence optimal plant density of East African highland bananas (Musa, AAA-EA) in low input cropping systems. Sci Hort. 150:299-311.

41. Nooriyan Soroor E, Rouzbehan Y, Alipour D. 2013. Effect of Echium amoenum extract on the growth rate and fermentation parameters of Mehraban lambs. Anim Feed Sci Technol. 184:49-57.

42. Omidi Tabrizi AH. 2003. [Correletion between traits and path analysis for grain and oil yield in spring safflower]. Iran J Seed Plant Res. 18:229-240. (In Persian with English Summary).

43. Padmavathiamma PK, Li LY, Kumari UR. 2008. An experimental study of vermin-biowaste composting for agriculture soil improvement. Bioresource Technol. 99:1672-1681.

44. Raja Sekar K, Karmegan N. 2010. Earthworm casts as an alternate carrier material for biofertilizers: Assessment of endurance and viability of Azotobacter chroococcum, Bacillus megaterium and Rhizobium leguminosarum. Sci Hort. 124:286-289.

45. Rezaee M, Baradaran R. 2011. [Effects of biofertilizers on the yield and yield components of pot marigold (Calendula officinalis)]. Iran J Med Aroma Plants. 29:635-650. (In Persian with English Summary).

46. Rezvani Moghaddam P, Aminghafuri A, Bakhshaee S, Jafari L. 2013. [Evaluation of effect of biofetilizer and organic fertilizer on some quantitative characteristics and amount of oil of Satureja hortensis]. Iran J Agroecol. 5:105-112. (In Persian with English Summary).

47. Robin A, Szmidt RAK, Dickson W. 2001. Use of compost in agriculture, Frequently Asked Questions (FAQs). Remade Scotland. 324:336.

48. Sabahi H, Takafooyan J, Mahdavi Damghani AM, Liaghati H. 2010. [Effects of integrated application of farmyard manure, plant growth promoting rhizobacteria and chemical fertilizers on production of canola (Brassica napus) in saline soil of Qum]. Iran J Agroecol. 2:287-291. (In Persian with English Summary).

49. Sayyah M, Boostani H, Pakseresht S, Malaieri A. 2009. Efficacy of aqueous extract of Echium amoenum in treatment of obsessive-compulsive disorder. Prog Neuro-Psychopharma Biol Psychiat. 33:1513-1516.

50. Shamsodin SM, Maghsudi K, Farahbakhsh H, Naseralavi M. 2007. [Compost and control of soil erosion]. $2^{\text {nd }}$ National Congress of Ecological Agriculture, 25-26 October, Gorgan, Iran. (In Persian with English Summary).

51. Singh JS, Pandey VC, Singh DP. 2011. Efficient soil microorganisms: A new dimension for sustainable agriculture and environmental development. Agr, Ecosyst Environ. 140:339-353.

52. Singh B, Singh G, Pandey VP. 2012. Path analysis for seed yield and its component characters in fenugreek (Trigonella foenum-graecum). New Agric. 23:185-187.

53. Tahami Zarandi SMK, Rezvani Moghaddam P, Jahan M. 2010. [Comparison of effect of organic and chemical fertilizers on yield and essential oil percentage of basil (Ocimum basilicum)]. Iran J Agroecol. 2:63-74. (In Persian with English Summary).

54. Toebe M, Filho AC. 2013. Multicollinearity in path analysis of maize (Zea mays). J Cereal Sci. 57:453-462.

55. Tollenaar M. 1991. Physiological basis of genetic improvement of maize hybrids in Ontario from 1959 to 1988. Crop Sci. 31:119-124.

Page 19/21 
56. Wu SC, Caob ZH, Lib ZG, Cheunga KC, Wong MH. 2005. Effects of biofertilizers containing N-fixer, P and K solubilizers and AM fungi on maize growth: a greenhouse trial. Geoderma. 125:155-166.

57. Zhang Sh, Liao X, Zhang Ch, Xu H. 2012. Influences of plant density on the seed yield and oil content of winter oilseed rape (Brassica napus). Ind Crop Prod. 40:27-32.

\section{Figures}

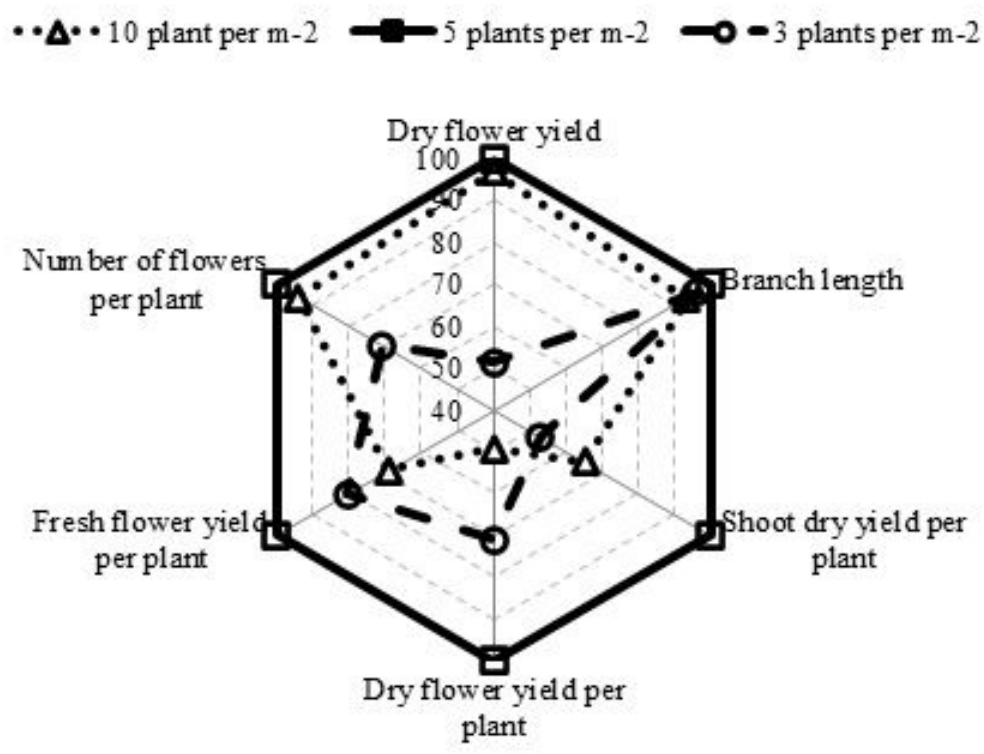

\section{Figure 1}

Relative comparison of Echium amoenum growth characteristics under three plant densities: 5 plants per m-2 (continuous line), 10 plants per $\mathrm{m}-2$ (dotted line), and 3 plants per $\mathrm{m}-2$ (cut line).
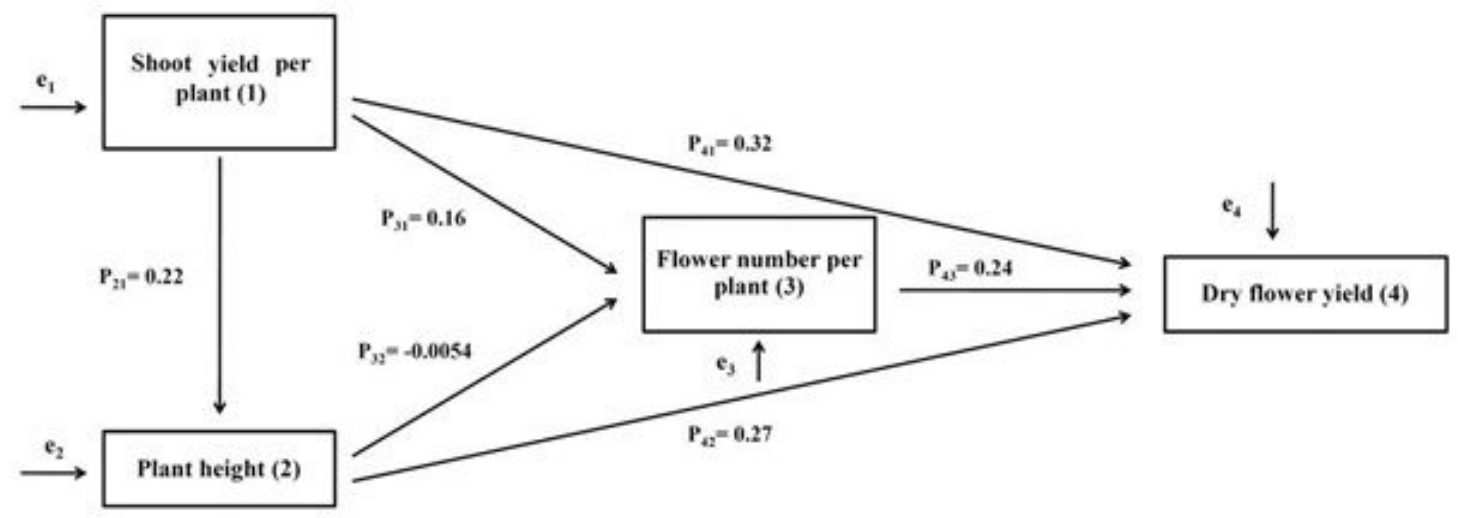

\section{Figure 2}

Path coefficients diagram showing the causality path of dry flower yield forming and growth characteristics of Echium amoenum as a result of application of organic and chemical fertilizers and different plant densities (e represents non-measurable errors). 

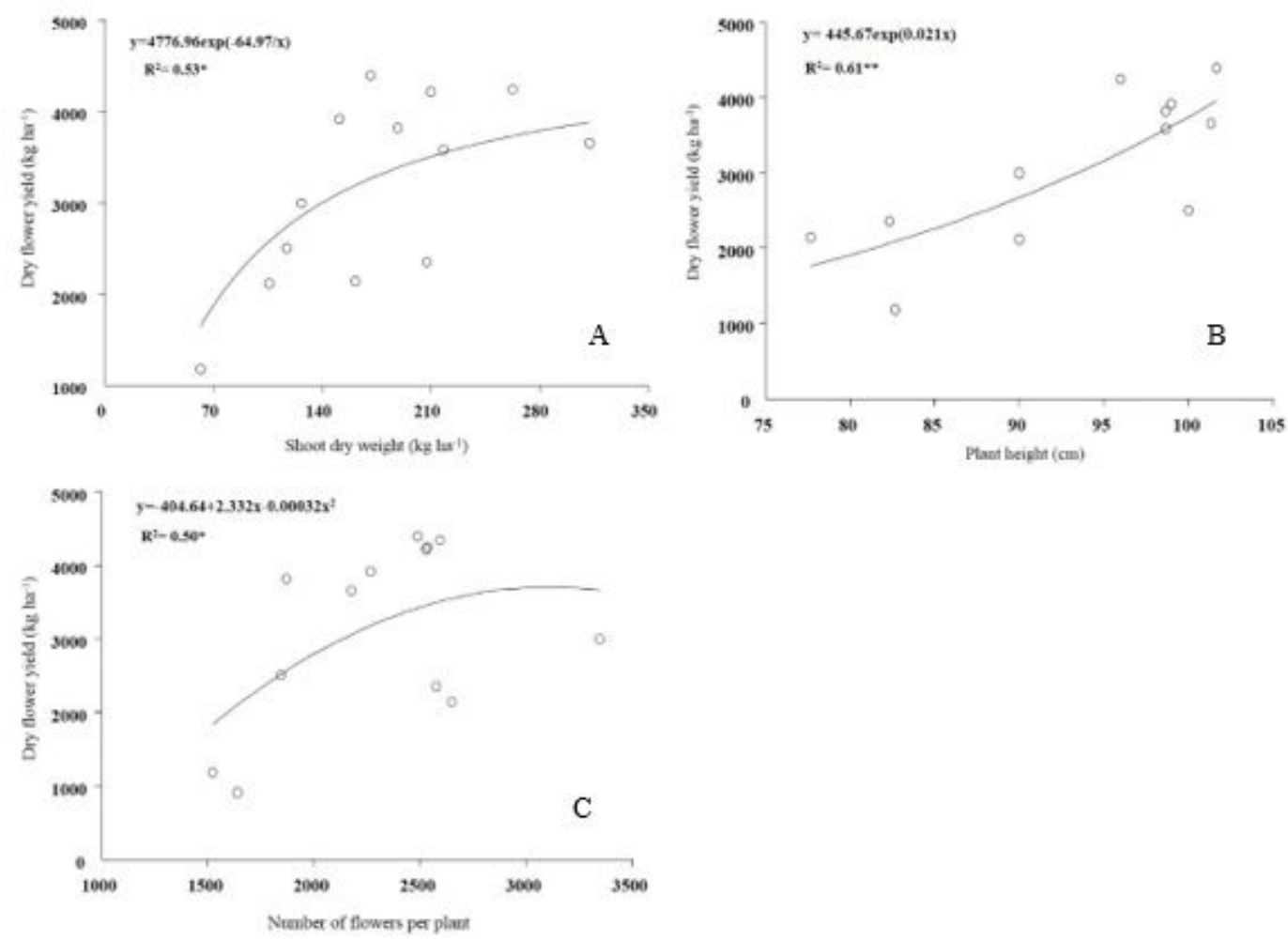

\section{Figure 3}

Regression functions of changes of dry flower yield of Echium amoenum against shoot dry weight (A), plant height (B) and flower number per plant (C).
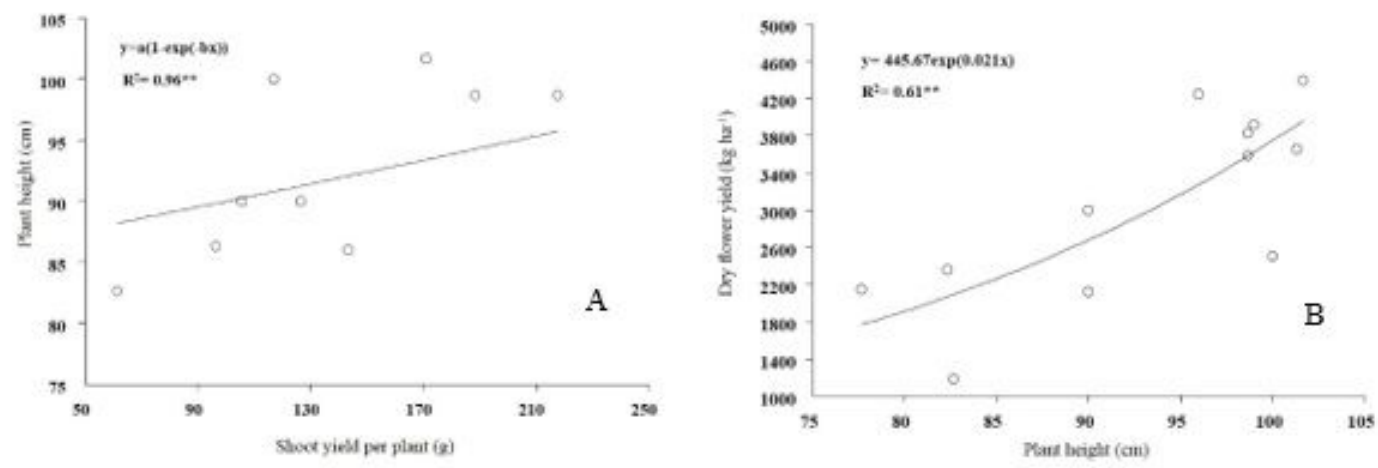

\section{Figure 4}

Indirect effect of shoot weight per plant on the dry flower yield of Echium amoenum mediated by plant height: (A) exponential relation between plant height and shoot yield, (B) exponential relation between plant height and dry flower yield. 